\title{
Influence of Algae Age and Population on the Response to $\mathrm{TiO}_{2}$ Nanoparticles
}

\author{
David M. Metzler ${ }^{1}$, Ayca Erdem ${ }^{2, *}$ and Chin Pao Huang ${ }^{3}$ \\ 1 School of Arts and Sciences, Gwynedd Mercy University, Gwynedd Valley, PA 19437, USA; \\ metzler.d@gmercyu.edu \\ 2 Department of Environmental Engineering, Akdeniz University, Antalya 07058, Turkey \\ 3 Department of Civil and Environmental Engineering, University of Delaware, Newark, DE 19711, USA; \\ huang@udel.edu \\ * Correspondence: ayerdem@akdeniz.edu.tr; Tel.: +90-242-310-6329
}

Received: 2 February 2018; Accepted: 21 March 2018; Published: 25 March 2018

\begin{abstract}
This work shows the influence of algae age (at the time of the exposure) and the initial algae population on the response of green algae Raphidocelis subcapitata to titanium dioxide nanoparticles $\left(\mathrm{TiO}_{2} \mathrm{NPs}\right)$. The different algae age was obtained by changes in flow rate of continually stirred tank reactors prior to NP exposure. Increased algae age led to a decreased growth, variations in chlorophyll content, and an increased lipid peroxidation. Increased initial algae population $\left(0.3-4.2 \times 10^{6}\right.$ cells $\left./ \mathrm{mL}\right)$ at a constant NP concentration $(100 \mathrm{mg} / \mathrm{L})$ caused a decline in the growth of algae. With increased initial algae population, the lipid peroxidation and chlorophyll both initially decreased and then increased. Lipid peroxidation had $4 \times$ the amount of the control at high and low initial population but, at mid-ranged initial population, had approximately half the control value. Chlorophyll a results also showed a similar trend. These results indicate that the physiological state of the algae is important for the toxicological effect of $\mathrm{TiO}_{2} \mathrm{NPs}$. The condition of algae and exposure regime must be considered in detail when assessing the toxicological response of NPs to algae.
\end{abstract}

Keywords: algae age; lipid peroxidation; chlorophyll; $\mathrm{TiO}_{2}$ nanoparticles

\section{Introduction}

Titanium dioxide $\left(\mathrm{TiO}_{2}\right)$ nanoparticles (NPs) are extensively used in various industrial and consumer products [1-4]. As the production and usage of $\mathrm{TiO}_{2}$ increases, the release of NPs via spills, end use, and/or degradation of products into the environment also increases. The expected environmental loads of $\mathrm{TiO}_{2} \mathrm{NPs}$ are 2-6 $\times 10^{6}$ tons [5], and the estimated worldwide production of $\mathrm{TiO}_{2} \mathrm{NPs}$ is up to $10^{5}$ tons/year [6]. In addition to those, Keller et al. [7] estimated the total $\mathrm{TiO}_{2} \mathrm{NP}$ release into air, water, soil, and landfill as 88,000 tons/year. As a result, the expected environmental concentrations of $\mathrm{TiO}_{2} \mathrm{NPs}$ are higher than other metal oxide NPs due to their excessive production amounts and applications [7]. The predicted concentrations of nano- $\mathrm{TiO}_{2}$ in freshwater and in sediment are at $\mathrm{ppb}$ and ppm levels, respectively [8-11].

$\mathrm{TiO}_{2}$ generates reactive oxygen species (ROS) such as superoxide anions, hydrogen peroxide, and singlet oxygen, which can be harmful to organisms. The magnitude to which the ROS are generated depends on particle size, quantum yield, and light intensity. $\mathrm{TiO}_{2}$ has an activation wavelength between 376 and $413 \mathrm{~nm}$ in the UV range of the electromagnetic spectrum [12-15]. Studies have shown the effects of UV radiation [16-19], solar simulated light [20-26], and natural sunlight [27,28] with $\mathrm{TiO}_{2}$ $\mathrm{NP}$ on aquatic organisms in terms of mortality, reduced growth, and DNA deformation.

Green algae have been used as an indicator organism to study the toxicity of nanomaterials due to the ease of cultivation and performing lab-based assessments [29]. Standard procedures for toxicology 
tests are agreed upon by experts in toxicology, chemistry, and biology so that results are comparable. From these results, conclusions can be drawn about and between toxicants. Standard protocols for algae have been implemented around the world, including the Guideline for Testing of Chemicals, No. 201: Freshwater Alga and Cyanobacteria, Growth Inhibition Test [30], US EPA-821-R-02-013.2002: Short-Term Methods for Estimating the Chronic Toxicity of Effluents and Receiving Waters to Freshwater Organisms [31], and ISO 8692: Water Quality-Fresh Water Algal Growth Inhibition Test with Unicellular Green Algae [32]. These methods are implemented for legislative authorities to use as references and compare with studies that present data with similar initial algae density, light intensity, and organism age values. The results, although comparable, might not truly represent the natural environment. Cell populations and cell age are not constant as they are in a laboratory setting. Factors that are not constant in the natural environment include light intensity, algae density, and cellular age [33].

Limited studies have shown the effect of age on the toxicity of metals to various species. Hoang and Klaine [34] studied the toxicity of $\mathrm{Cu}, \mathrm{Zn}, \mathrm{Se}$, and As on Daphnia magna. After dosing organisms at various ages with a $12 \mathrm{~h}$ pulse of one of the metals, biphasic toxicity with respect to mortality and reproduction was observed over 21 days of the experiment. D. magna mortality increased, while reproduction decreased as age increased. Rogevich et al. [35] showed the effect of age on $\mathrm{Cu}$ toxicity to the Florida apple snail (Pomacea paludosa). As the age of the organism increased at the time of exposure from 2 to 120 days, the $96 \mathrm{~h} \mathrm{LC}_{50}$ (lethal concentration for $50 \%$ of the population) increased from $34.2 \pm 4.4$ to $182 \pm 65.1 \mu \mathrm{g} / \mathrm{L} \mathrm{Cu}$. In the study by Lesser [36], changes in the maximum rate of photosynthesis $\left(\mathrm{P}_{\max }\right)$ was observed. As the experimental culture age increased from 0 to 22 days, the $\mathrm{P}_{\max }$ decreased, while the shape of the curve remained nearly the same. The toxicity of Ni was most strongly correlated to that of the age of Pimephales promelas [37]. Stevenson et al. [38] showed the responses of Chlamydomonas reinhardtii from fast, slowing, and stationary growth phases to silver (Ag) NPs in terms of chlorophyll ( $\mathrm{Chl}$ ) measurements. Algae from fast growing phases showed more sensitivity to Ag NPs than did those from later phases. The Chl content of fast-growth-phase algae decreased from 0.3 (Day 1) to $0.01 \mu \mathrm{g} / \mathrm{L}$ (Day 3). The results from slow-growth-phase cultures showed a two-step decline during the exposure: (i) within the first three days, Chl content decreased from approximately 100 to $30 \mu \mathrm{g} / \mathrm{L}$ following a $10 \mu \mathrm{g} / \mathrm{L}$ of recovery; (ii) in the last four days, Chl content decreased from approximately 40 to $20 \mu \mathrm{g} / \mathrm{L}$.

The age of organisms can affect the toxicity of stressors. The interaction between the stressor and organism is an important factor, known as body burden. Body burden can be defined as the amount of chemical that is present in a body at a given time, usually given in mass of chemical per mass of organism. This term is more directly related to the toxicological effect than exposure concentration due to the extent of bioavailability of a toxicant. Two methods can be used to vary the body burden: (1) varying the population density while the toxicant concentration is kept constant or (2) varying the toxicant concentration while the populations are held constant. Moreno-Garrido et al. [39] demonstrated how varying the initial algal population density affects the $\mathrm{EC}_{50}$ (half maximal effect concentration) values of the toxicant-in this case, $\mathrm{Cu}$. The authors refer to the exposure per algae cell as the "toxic cellular quota." The authors asserted that there was a linear relationship between the $\log \mathrm{Cu}$ cellular quota and the \% growth inhibition. Table 1 summarizes the results of the studies employing different initial algae populations, test media, ionic strength, and particle sizes. The results were depicted in $\mathrm{EC}_{50}(\mathrm{mg} / \mathrm{L})$. Most of the studies used an algal medium as a test solution, and, even though the same protocols $[30,31]$ were used, the initial algae population varied between $10^{4}$ and $3.5 \times 10^{6} \mathrm{cell} / \mathrm{mL}$, and the ionic strength of the test solutions varied from 0.5 to $8 \mathrm{mM}$. As a result of using different test media with different ionic strengths and other conditions (not depicted in Table 1), the particle sizes and $\mathrm{EC}_{50}$ values were not comparable. 
Table 1. Data on ecotoxic effects of $\mathrm{TiO}_{2}$ nanoparticles on Raphidocelis subcapitata.

\begin{tabular}{|c|c|c|c|c|c|}
\hline $\begin{array}{c}\text { Initial Algae } \\
\text { Population } \\
\text { (Cell/mL) }\end{array}$ & Test Media Type & $\begin{array}{l}\text { Calculated Ionic } \\
\text { Strength (mM) }\end{array}$ & $\begin{array}{l}\text { Particle Size } \\
\quad(\mathrm{nm})\end{array}$ & $\begin{array}{c}\text { Half Maximal Effect } \\
\text { Concentration } \\
\left(\mathrm{EC}_{50}, \mathrm{mg} / \mathrm{L}\right)\end{array}$ & $\begin{array}{c}\text { Reference } \\
\text { No }\end{array}$ \\
\hline $10^{4}$ & Algal medium & 1.5 & 21 & 2.53 & [18] \\
\hline $1.4 \pm 0.9 \times 10^{6}$ & Algal medium & 640 & 42 & 25.5 & [21] \\
\hline \multirow{4}{*}{$2.6 \pm 1.1 \times 10^{5}$} & \multirow{4}{*}{$\begin{array}{l}\text { Synthetic } \\
\text { freshwater } \\
\text { solutions }\end{array}$} & 0.5 & $212 \pm 19$ & $4.16 \pm 0.05$ & \multirow{4}{*}{ [26] } \\
\hline & & 1 & $287 \pm 25$ & $3.58 \pm 0.16$ & \\
\hline & & 2 & $546 \pm 71$ & $9.32 \pm 0.11$ & \\
\hline & & 8 & $1428 \pm 202$ & $12.14 \pm 0.09$ & \\
\hline $10^{5}$ & Algal medium & 640 & 140 & 87 & [40] \\
\hline $10^{4}$ & Algal medium & 1.5 & $\sim 30$ & 71.1 & [41] \\
\hline $3.5 \times 10^{6}$ & Algal medium & 640 & $25-70$ & 5.38 & [42] \\
\hline $3 \times 10^{6}$ & Algal medium & 620 & 140 and 380 & 87 and 61 & [43] \\
\hline
\end{tabular}

Since the physiological state and the age of algae are important factors determining their response to any toxicant, different initial cell densities and cell ages were applied in our study to address two questions: (i) whether various initial cell densities have an important role in ecotoxicity of $\mathrm{TiO}_{2} \mathrm{NPs}_{\text {, }}$ and (ii) how the physiology of algae affects the ecotoxicity of $\mathrm{TiO}_{2}$.

\section{Materials and Methods}

\subsection{Algae}

Algae specimens of Raphidocelis subcapitata (formerly Pseudokirchneriella subcapitata and Selenastrum capricornutum) were purchased from Aquatic Biosystems (Fort Collins, CO, USA). The algal inoculums were stored at $4{ }^{\circ} \mathrm{C}$ in the dark for no longer than 6 months. It was cultured in algal medium using a continually stirred tank reactor (CSTR) according to Metzler [43]. Algal growth medium $(0.642 \mathrm{M})$ was prepared with macronutrients $\left(\mathrm{MgCl}_{2} \cdot 6 \mathrm{H}_{2} \mathrm{O}: 6.08 \mathrm{~g}, \mathrm{CaCl}_{2} \cdot 2 \mathrm{H}_{2} \mathrm{O}: 2.20 \mathrm{~g}, \mathrm{NaNO}_{3}\right.$ : $\left.12.75 \mathrm{~g}, \mathrm{MgSO}_{4} \cdot 7 \mathrm{H}_{2} \mathrm{O}: 7.35 \mathrm{~g}, \mathrm{~K}_{2} \mathrm{HPO}_{4}: 0.522 \mathrm{~g}, \mathrm{NaHCO}_{3}: 7.50 \mathrm{~g}\right)$ and micronutrients $\left(\mathrm{H}_{3} \mathrm{BO}_{3}: 92.8 \mathrm{mg}\right.$, $\mathrm{MnCl}_{2} \cdot 4 \mathrm{H}_{2} \mathrm{O}: 208.0 \mathrm{mg}, \mathrm{ZnCl}_{2}: 1.64 \mathrm{mg}, \mathrm{FeCl}_{3} \cdot 6 \mathrm{H}_{2} \mathrm{O}: 79.9 \mathrm{mg}, \mathrm{CoCl}_{2} \cdot 6 \mathrm{H}_{2} \mathrm{O}: 0.714 \mathrm{mg}, \mathrm{Na}_{2} \mathrm{MoO}_{4} \cdot 2 \mathrm{H}_{2} \mathrm{O}:$ $3.63 \mathrm{mg}, \mathrm{CuCl}_{2} \cdot 2 \mathrm{H}_{2} \mathrm{O}: 0.006 \mathrm{mg}, \mathrm{Na}_{2}$ EDTA $2 \mathrm{H}_{2} \mathrm{O}: 150.0 \mathrm{mg}, \mathrm{Na}_{2} \mathrm{SeO}_{4}: 1.196 \mathrm{mg}$ ) dissolved in $500 \mathrm{~mL}$ milli-Q water [31].

The algae solutions used in zeta potential measurements were filtered using glass fiber filter paper (Whatman Inc., Florham Park, NJ, USA). The filter paper was soaked in an Erlenmeyer flask containing a $0.65 \mathrm{mM} \mathrm{NaCl}$ solution. The $\mathrm{pH}$ of the algal suspensions was adjusted to 3.0, 4.5, 5.6, 7.0, and 9.2 with varying amounts of $\mathrm{HCl}, \mathrm{NaHCO}_{3}$, and $\mathrm{Na}_{2} \mathrm{CO}_{3}$, and the zeta potential of the algal solutions was finally measured using a Malvern Nano-ZS (Westborough, MA, USA).

In order to test the effect of the initial population density, the CSTRs had a 3-day hydraulic retention time (HRT). Initial cell densities were between 0.31 and $4.19 \times 10^{6}$ cells $/ \mathrm{mL}$ in the sample. When the algal population age was tested, the HRT of the CSTRs were varied between 2 and 25 days, with a cell density of $9.77 \pm 4.87 \times 10^{5}$ cells $/ \mathrm{mL}$ in sample. Prior to the addition of the algae to the test beakers, the absorbance, cell density, and $\mathrm{Chl} a$ were measured using a $\mathrm{HACH}$ spectrophotometer [38]. Experiments were run in triplicate.

\subsection{Nanoparticles}

$\mathrm{TiO}_{2}$ (P25) was purchased from Degussa Corp. (Parsippany, NJ, USA). The surface area was measured with $\mathrm{N}_{2}$-sorption with a Quantachrome model Nova 2000. $\mathrm{TiO}_{2} \mathrm{NP}$ particle size was

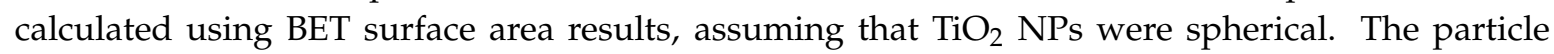
size and the zeta potential of $\mathrm{TiO}_{2}$ were measured using a Malvern Nano-ZS Particle and ZetaSizer (Westborough, MA, USA). Dynamic light scattering (DLS) was performed to calculate the particle sizes.

Stock suspensions of either 2 or $4 \mathrm{~g} / \mathrm{L}$ were made in algal growth media [6] without any prior treatment to the nanoparticles. The suspensions were autoclaved for $20 \mathrm{~min}$ at $120^{\circ} \mathrm{C}$ at least one day 
prior to use, and stored at $21 \pm 1^{\circ} \mathrm{C}$. Prior to the exposure experiments, sonication was applied using an ultrasonic homogenizer ( $600 \mathrm{~W}, 20 \mathrm{kHz}$, Cole-Parmer, Chicago, IL, USA) equipped with a titanium probe transducer (Model CV 17, Cole Parmer) for 5 min at an energy intensity of $24 \mathrm{~W}$.

\subsection{Test Chambers}

Three test chambers with dimensions of $80 \times 60 \times 70 \mathrm{~cm}(\mathrm{H} \times \mathrm{W} \times \mathrm{L})$ were covered in black cloth. An orbital platform shaker holding eight, $1 \mathrm{~L}$ plastic beakers was used to conduct the exposure experiments. One bank consisting of six lights (model GE PL/AQ F12T20, General Electric, Fairfield, CT; Sylvania Gro-lux F12T20/Gro/AQ and F12T20/Gro/AQ/WS, Rutherford, NJ, USA) was suspended approximately $42 \mathrm{~cm}$ from the bottom of the test beakers. The light intensity at the top of the beaker was $1632 \pm 409$ lux. The light sources emitted light at a spectrum mimicking that of solar light (Figure 1). A centrifugal mini-blowers and a muffin fan, one on each side of the chamber, removed excess heat generated by the lights. The shaker was set to mix at $150 \mathrm{rpm}$ throughout all experiments.

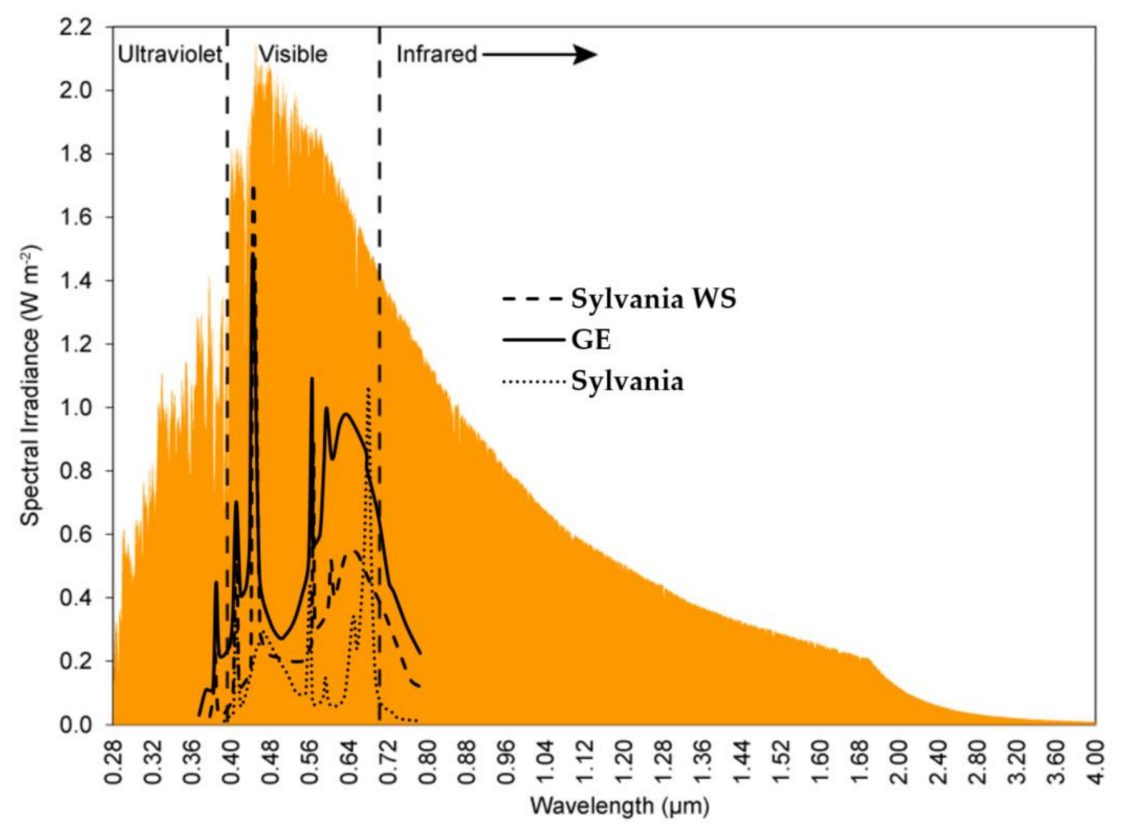

Figure 1. Light spectrum of solar light (orange colored area) [44] and light sources used in the study (Sylvania WS (一): F12T20/Gro/AQ/WS, GE (-): GE PL/AQ F12T20, and Sylvania ( $\cdots$ ): Gro-lux F12T20/Gro/AQ).

\subsection{Exposure Regime}

Aliquots of particles were added to $1 \mathrm{~L}$ plastic beakers to make final concentrations of 100 or $1000 \mathrm{mg} / \mathrm{L}$. Algal growth media was then added to the beakers $(\leq 100 \mathrm{~mL})$ in various volumes depending on the experimental setup listed below. The samples were then sonicated for $2 \mathrm{~min}$ at $48 \mathrm{~W}$ $(8 \%$ of $600 \mathrm{~W}$ ) with a $9 \mathrm{~mm}$ probe using a Cole Parmer Ultrasonic Homogenizer Series 4710 (Cole Parmer, Chicago, IL, USA). The samples were then allowed to equilibrate for $1 \mathrm{~h}$, after which the $\%$ transmission was measured on a Hewlett-Packard 8542A UV-vis (Fall River, DE, USA), and the spectrum was recorded. Once the algae were added, the final volume was $200 \mathrm{~mL}$. Three replicates were run on separate occasions.

\subsection{Measurements}

The $\mathrm{pH}$ and the temperatures of the growth chambers were measured each day to ensure stability. At the end of the 4-day exposure, the remaining sample volume was determined. Forty milliliters of sample was collected to analyze Chl $a$, and $12 \mathrm{~mL}$ was collected to analyze cell density and lipid 
peroxidation. The samples were stored at $4{ }^{\circ} \mathrm{C}$ in the dark until analyzed. Weber et al. [45] reported that $\mathrm{Chl}$ content would remain stable for a maximum of seven days.

Cell densities were measured by direct cell counts. Sample $(1 \mathrm{~mL})$ was diluted in 0.5 moles $/ \mathrm{L}$ lauryl sulfate $(1 \mathrm{~mL})$ and vortexed for $2 \mathrm{~min}$. A $100 \mu \mathrm{L}$ of each sample was counted 4 times using a hemocytometer, and Olympus AX70 microscope. Cell densities were converted into total cell population by multiplying the cell counts by the volume of sample remaining in the $1 \mathrm{~L}$ test beakers at the end of the test duration. The total cell populations were then corrected for the initial population and normalized based on the control, using the following equation:

$$
R_{s}=\frac{(\rho \times V)_{t}}{(\rho \times V)_{c}}
$$

where Rs is the normalized specific growth (NSG), $\rho$ is the cell density (cells $/ \mathrm{mL}$ ), $V$ is the volume of sample at the end of the 4-day exposure period (mL), $t$ is the sample exposed to NPs, and $c$ is the control sample with no treatment.

To analyze Chl a content, $40 \mathrm{~mL}$ of sample were concentrated to between 0.5 and $3 \mathrm{~mL} \mathrm{Chl} \mathrm{[39].}$ The concentrated samples were brought to $3 \mathrm{~mL}$ with $\mathrm{Mg}$-acetone. The samples were homogenized for $1 \mathrm{~min}$ at $2000 \mathrm{rpm}$ and were then steeped at $4{ }^{\circ} \mathrm{C}$ in the dark for $2 \mathrm{~h}$. After the steep time, the samples were centrifuged for $30 \mathrm{~min}$ at $664 \mathrm{~g}$. The optical density of the supernatant was measured at 750 and $664 \mathrm{~nm}$ with a UV-vis spectrophotometer ( $\mathrm{HP} 8525 \mathrm{~A}) . \mathrm{HCl}(0.1 \mathrm{~mL}$ of $0.1 \mathrm{~N})$ was added to the samples. After $90 \mathrm{~s}$, the optical density was re-measured at 750 and $665 \mathrm{~nm}$. The concentration of Chl a ([Chla] in $\left.\mathrm{mg}-\mathrm{Chla} / \mathrm{m}^{3}\right)$ ) was calculated using the following equation:

$$
[\text { Chla }]=\frac{26.7 \times(A 664-A 665) \times V_{1}}{V_{2} \times l}
$$

where $A 664$ is the absorbance at $664 \mathrm{~nm}$ before adding acid, $A 665$ is the absorbance at $665 \mathrm{~nm}$ after adding acid, $V_{1}$ is the volume of the extract $(\mathrm{L}), V_{2}$ is the volume of sample $\left(\mathrm{m}^{3}\right)$, and $l$ is the width of the cuvette $(\mathrm{cm})$. The specific Chl a was calculated by the following expression:

$$
y=\frac{[\text { Chla }]}{\rho \times 10^{6}}
$$

where $y$ is the specific Chl a (mg Chla/cell), [Chla] is the concentration of Chl $a\left(\mathrm{mg} \mathrm{Chla} / \mathrm{m}^{3}\right)$, and $\rho$ is the cell density (cells $/ \mathrm{mL}$ ). The specific Chl $a, y$, was then normalized with respect to the control condition according to the following equation:

$$
Y=\frac{y}{y_{c}}
$$

where $Y$ is the normalized specific Chl $a$ (pg Chla/cell), $y$ is the specific Chl $a$ of samples (mg Chla/cell), and $y_{c}$ is the specific Chl $a$ of the control (mg Chla/cell).

Lipid peroxidation method was used following Maness' malondialdehyde (MDA) method [46]. A $1 \mathrm{~mL}$ sample was added to $2 \mathrm{~mL}$ of $10 \%$ trichloroacetic acid (TCA). The mixture was centrifuged for $45 \mathrm{~min}$ at $11,000 \mathrm{~g}$. The supernatant was added to $3 \mathrm{~mL}$ of $6.7 \mathrm{~g} / \mathrm{L}$ 2-thiobarbituric acid (TBA). The samples were heated in boiling water for $10 \mathrm{~min}$. After cooling, the samples were measured on a UV-vis spectrophotometer at 532 and $600 \mathrm{~nm}$ wavelengths. The absorbance at $532 \mathrm{~nm}$ was corrected for the background at $600 \mathrm{~nm}$ by subtracting the measurement at $600 \mathrm{~nm}$ from those at $532 \mathrm{~nm}$. Calibration standards were made from 1,1,3,3-tetramethoxypropane. Normalized specific lipid peroxidation $(Z)$ was calculated by the following equations:

$$
z=\frac{[M D A]}{\rho \times 10^{3}}
$$


where $z$ is the pmol $M D A$ /cell, $[M D A]$ is the concentration of $M D A$-TBA acid complex measured $(\mu \mathrm{M})$, and $\rho$ is the cell density (cells $/ \mathrm{mL}$ ). The $z$ value was then normalized against the control according to the following equation:

$$
Z=\frac{z}{z_{c}}
$$

where $\mathrm{Z}$ is the specific lipid peroxidation of the sample (pmol $M D A / c e l l)$, and $z_{c}$ is the specific lipid peroxidation of the control (pmol MDA/cell).

\section{Results and Discussions}

\subsection{Nanoparticle Characterization}

Since the surface chemistry of the NPs and the solution composition and chemistry play an important role in the process of aggregation/agglomeration of NPs [47,48], we obtained the surface area, size, and zeta potential values of $\mathrm{TiO}_{2} \mathrm{NPs}$ in algal media. The surface area of the $\mathrm{TiO}_{2} \mathrm{NPs}$ before exposure was measured with $\mathrm{N}_{2}$-sorption with a Quantachrome model Nova 2000 and found to be $44.0 \pm 2.9 \mathrm{~m}^{2} / \mathrm{g}$. The particle sizes before $(t=0)$ and after $(t=72 \mathrm{~h})$ the exposure measured with the DLS method were $35.1 \pm 2.1 \mathrm{~nm}$ and $294 \pm 28 \mathrm{~nm}$, respectively.

The zeta potential values of algae, $\mathrm{TiO}_{2} \mathrm{NPs}$, and algae $+\mathrm{TiO}_{2} \mathrm{NPs}$ are shown in Figure 2. The zero point charge (pHzpc) of $\mathrm{TiO}_{2}$ NPs was 6.4 and the same value was also reported by Lin et al. [49], where other studies showed pHzpc as 6.25 [50] and 6.3 [51]. The NPs and algae were negatively charged during the experiments. The zeta potential of the algae+ $\mathrm{TiO}_{2} \mathrm{NP}$ solution was also measured and found to be $-33 \mathrm{mV}$ at $\mathrm{pH} 7.3 \pm 0.5$. Similarly, it has been reported that with different algae per $\mathrm{TiO}_{2} \mathrm{NP}$ ratios, the zeta potential measurements were between -32 and $-36 \mathrm{mV}$ when the $\mathrm{pH}$ of the solution was around 7.2 [49]. Guzman et al. [52] noted that the $\mathrm{pH}$ of the solution increases the aggregation/agglomeration of the NPs when it approaches the pHzpc. Othman et al. [53] showed an enhanced stability of NPs with higher zeta potential magnitude. Ozkaleli and Erdem [26] reported a moderate stability of $\mathrm{TiO}_{2} \mathrm{NPs}$ in a very soft synthetic surface water samples with an ionic strength of $0.5 \mathrm{mM}$. In our results, a moderate stability was also achieved in algae $+\mathrm{TiO}_{2} \mathrm{NP}$ solutions.

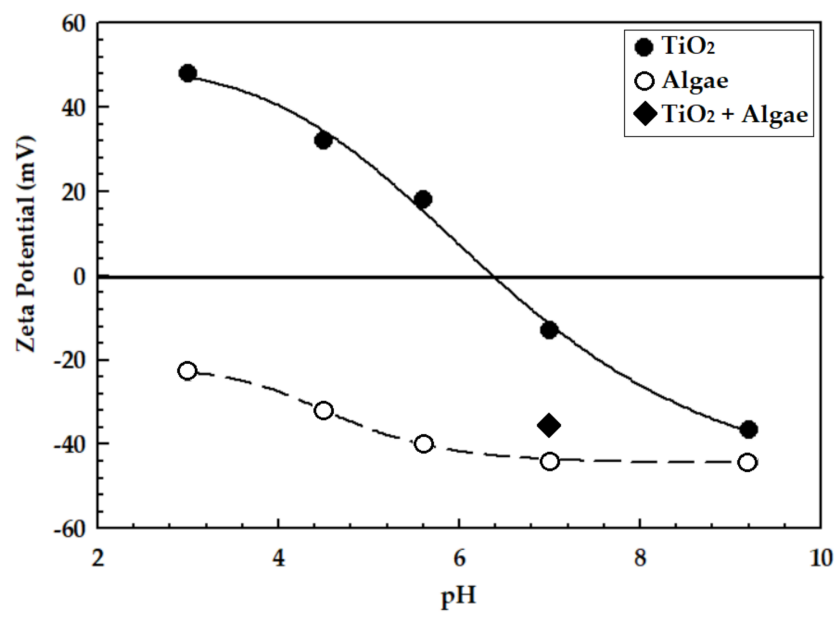

Figure 2. Zeta potential values of algae and $\mathrm{TiO}_{2} \mathrm{NPs}$ as a function of $\mathrm{pH}$.

\subsection{Initial Algal Population}

Laboratory protocols define specific parameters to test the effects of certain chemicals on indicator organisms; however, the natural environment does not always fall under these defined conditions. Therefore, a series of experiments were conducted to determine how population age and density affect the response to $\mathrm{TiO}_{2} \mathrm{NPs}$. 
The effect of body burden or $\mathrm{TiO}_{2}$ cellular quota was investigated by varying the initial cell density, while holding the concentration of $35.1 \pm 2.1 \mathrm{~nm} \mathrm{TiO}_{2} \mathrm{NPs}$ constant $(100 \mathrm{mg} / \mathrm{L})$, and the results are shown in Figures 3-5. The temperature for those experiments was $22.9 \pm 1.2{ }^{\circ} \mathrm{C}$. The average $\mathrm{pH}$ of the samples was $7.3 \pm 0.5$.

Figure 3 shows the effect of different initial cell population on NSG. As the initial cell population increased from $0.5 \times 10^{6}$ cells $/ \mathrm{mL}$ to $0.75 \times 10^{6}$ cells $/ \mathrm{mL}$, an initial increase in the NSG of $0.1-0.5$ was observed. However, with an initial cell population greater than $0.75 \times 10^{6}$ cells $/ \mathrm{mL}$, the NSG showed a constant value of approximately 0.6. The data was modeled with the following equation as follows:

$$
R_{s}=R_{\text {smax }} \times\left[\frac{\beta \times \rho_{i}}{1+\left(\beta \times \rho_{i}\right)}\right]
$$

where $R_{s}$ is the normalized cell growth, $R_{s m a x}$ is the maximum normalized cell growth, $\left[\rho_{i}\right]$ is the initial cell density, and $\beta$ is a curve shape factor. The data was fitted in an Excel solver, where $R_{\text {smax }}=0.685$, $\beta=4.673$, and the root mean squared error $(\mathrm{RSME})=0.498$. As the number of initial cells increased, the effect of the stress from the NPs decreased. This stress from body burden reached a steady state of around $1 \times 10^{6} \mathrm{cell} / \mathrm{mL}$.

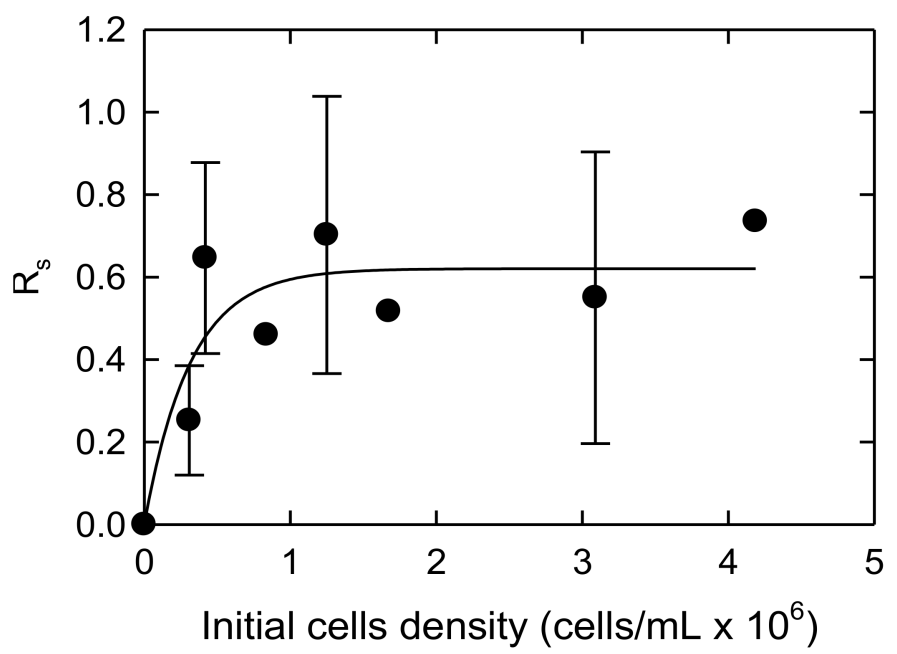

Figure 3. Normalized specific growth plotted against the initial cell density. The line is fitted using the empirical Equation (7).

Figure 4 represents the normalized specific $C h l a(Y)$ for varying initial cell concentrations at $100 \mathrm{mg} / \mathrm{L} \mathrm{TiO}_{2}$ NPs. As cell population increased from approximately $0.5 \times 10^{6}$ to $1 \times 10^{6} \mathrm{cell} / \mathrm{mL}$, the $Y$ decreased from approximately $3.1 \times 10^{6}$ to $0.5 \times 10^{6}$, of the control. From an initial cell population of approximately $1.8 \times 10^{6}$ to $3.1 \times 10^{6}$, there was no change in $Y$. As the initial cell population increased from $3.1 \times 10^{6}$ to greater than $4 \times 10^{6}$ cells $/ \mathrm{mL}, Y$ increased from approximately $1 \times 10^{6}$ to $3.1 \times 10^{6}$, of the control. Two outlier data points were excluded from the set. The outliers are represented by open circle symbols in Figure 3. To fit the data on the graph, the outlier values were divided using Equation (8). The data was fitted in SigmaPlot ver. 9.01 with empirical second-order polynomial Equation (8).

$$
Y=Y_{0}+a\left(\rho_{i}\right)+b\left(\rho_{i}\right)^{2}
$$

$\mathrm{Y}_{0}$ is the minimum value of the normalized specific Chl $a,\left[\rho_{i}\right]$ is the initial cell density (cells $/ \mathrm{mL}$ ), and $a$ and $b$ are the fitting parameters $\left(\mathrm{r}^{2}=0.547\right)$. At a steady concentration of NPs, the number of nanoparticles on each algae cell increased as the initial cell density decreased. These results agree with results from Wu et al. [54], who found that Chl a content increased under low light conditions, and high light conditions produced more Chl $a$ than an intermediate photon flux. The amount of light 
reaching the algae cells in this experiment would vary with the concentration of NPs per algae cell. This reinforces the idea of a shading effect, where less light reaches the algae cells.

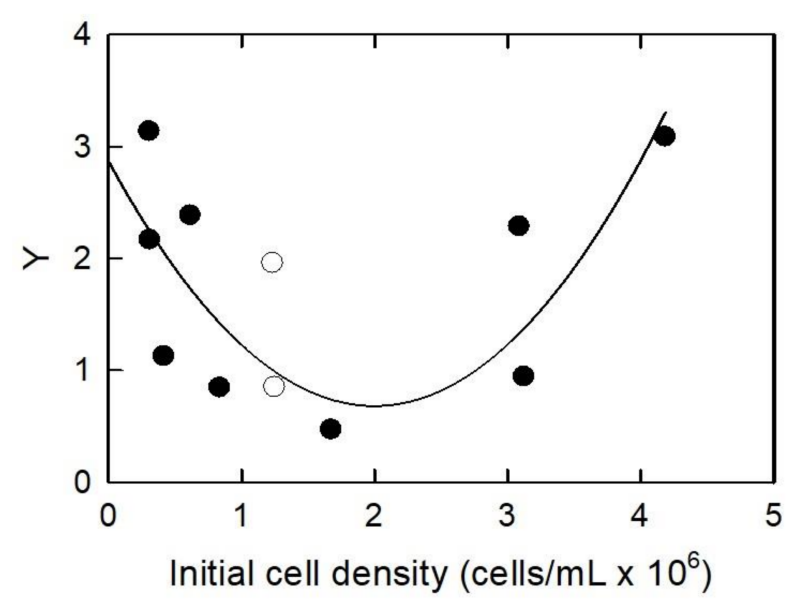

Figure 4. Normalized specific chlorophyll a plotted against the initial cell density. Closed symbols are data points. Open symbols are data that were considered outliers. Values of outliers are $11 \times$ plotted value. Line is fitted using the empirical Equation (8).

Figure 5 shows the normalized lipid peroxidation $(Z)$ of different initial cell populations. As the initial cell density increased from $0.5 \times 10^{6}$ to about $2 \times 10^{6}$ cells $/ \mathrm{mL}$, the $Z$ decreased from approximately 2 to 1 . As cell density increased greater than $2 \times 10^{6}$ cells $/ \mathrm{mL}$, the $Z$ increased to about 5. The data was fitted in SigmaPlot ver. 9.01 with an empirical second-order polynomial:

$$
Z=Z_{0}+c\left(\rho_{i}\right)+d\left(\rho_{i}\right)^{2}
$$

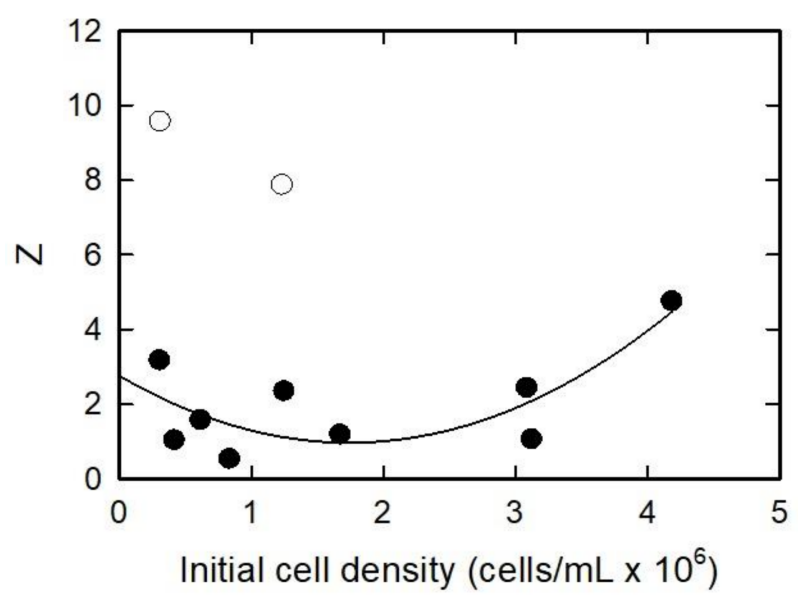

Figure 5. Normalized specific lipid oxidation plotted against the initial cell density. Closed symbols are fitted data points. Open symbols are data that were considered outliers and not included in the fitting. Line is fitted using the empirical Equation (9).

$Z_{0}$ is the normalized specific lipid peroxidation minimum value, $\left(\rho_{i}\right)$ is the initial cell density (cells $/ \mathrm{mL}$ ), and $c$ and $d$ are the fitting parameters. The data fit the model reasonably well with an $\mathrm{r}^{2}$ of 0.598 . During photosynthesis, reactive oxygen species (ROS) are generated. Under a moderate stress this can lead to the chloroplast releasing an excess amounts of ROS, which the cell cannot regulate [55]. From these results, the increased $Z_{0}$ at low initial cell densities could be attributed to an excess of internal ROS species from the increased Chl $a$ on a per cell basis while the cells are under 
stress. The algae cells are considered under "moderate stress" as defined by Dietz et al. [55] under the conditions of the experiment. As the initial cell density increases the algae cell are less stressed, on a per cell basis. The algae cells produce less Chl a per cell, which will result in less internal ROS and the $Z$ value will decrease. At the initial cell densities above $2 \times 10^{6}$ cells $/ \mathrm{mL}$, the $Z$ increase is attributed to the interaction of the ROS generated from the $\mathrm{TiO}_{2} \mathrm{NPs}$.

\subsection{Algae at Various Hydraulic Residence Times}

The toxicological response of organisms has been linked to the age at which the organism was exposed. Muyseen and Janssen [56] observed that D. magna had different responses to $\mathrm{Zn}$ and $\mathrm{Cu}$, where the juveniles were more or equally as sensitive. The increased sensitivity was attributed to larger area/volume ratios, which led to a size-dependent uptake and higher metabolic rates of younger organisms. Similar findings were observed by Yu and Wang [57], Hutchinson et al. [58], and Stuhlbacher et al. [59]. The response to a stressor can be affected by an organism's physiological state. Bacteria and algae grown in a CSTR can be cultured to maintain the organism in a given physiological state, where the time is the flow rate of the CSTR.

The growth phase can be set by varying the flow rate in a CSTR. Therefore, flow rates were maintained between 5 and $62 \mathrm{~mL} / \mathrm{h}$, which correspond to a 25 and 2 day HRT (d). Figures 6-9 show the results of culturing the algae at various $H R T$ values, and the response $\left(R_{\mathrm{s}}, Y\right.$, and $\left.Z\right)$ to two concentrations of $35.1 \pm 2.1 \mathrm{~nm} \mathrm{TiO}_{2}$. The temperature for this experiment was $23.0 \pm 1.2{ }^{\circ} \mathrm{C}$. The average $\mathrm{pH}$ of the samples was $7.5 \pm 1.0$.

Figure 6 shows a plot of the $R_{s}$ against the HRT. As the HRT for the $100 \mathrm{mg} / \mathrm{L}$ treatment (from 2 to $10 \mathrm{HRT}$ ) increased, the $R_{S}$ deceased for both 100 and $1000 \mathrm{mg} / \mathrm{L}$ treatments. The response is biphasic. The $R_{S}$ decreases from 1.4 to 0.35 as the $H R T$ increased to $10 \mathrm{~d}$. At $H R T>10$, the values for $R_{s}$ are between 0.35 and 0.74 , with a slope of near zero. For the $1000 \mathrm{mg} / \mathrm{L}$ treatment, the $R_{s}$ decreased from 0.62 to 0.09 from 2 to $10 H R T$, respectively. Moreover at $H R T>10$, the $R s$ for the $1000 \mathrm{mg} / \mathrm{L}$ treatment remains relatively constant at 0.23 . The data was fitted a modified three-parameter exponential decay equation from SigmaPlot version 9.01. The equation used is as follows:

$$
R_{s}=f \times e\left(\frac{g}{H R T+h}\right)
$$

where $H R T$ is the hydraulic retention time $(d)$, and $f, g$, and $\mathrm{h}$ are fitted constants. $R$-squared values were 0.785 and 0.842 for the 100 and $1000 \mathrm{mg} / \mathrm{L} \mathrm{TiO}_{2}$ treatments, respectively.

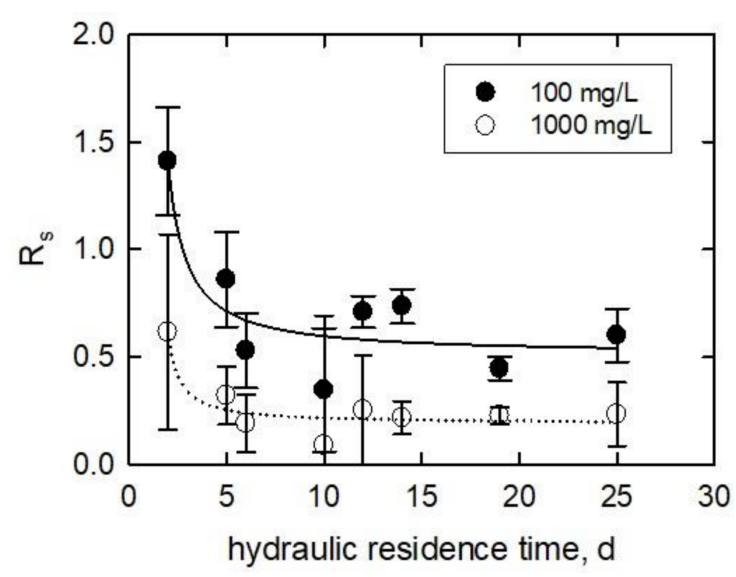

Figure 6. Normalized specific cell growth plotted against the hydraulic residence time of the continually stirred tank reactors in which the algae inoculums were cultured. Lines are fitted using Equation (10). 
Figure 7 is the $Y$ plotted as a function of $H R T$. In the $100 \mathrm{mg} / \mathrm{L}$ treatment, the $Y$ increased from 2 to 10 as the HRT increased from 2 to 16 days. From 16 to 25 days, the $Y$ decreased from 10 to 1 . The data was empirically fitted to a modified five-parameter Gaussian equation from SigmaPlot version 9.01. The equation is as follows:

$$
Y=Y_{0}+i \times e\left(-0.5 k \frac{H R T-H R T_{0}}{j}\right)
$$

$Y_{0}$ is the minimum value of the normalized specific Chl a, $H R T(\mathrm{~d})$ and $H R T_{0}(\mathrm{~d})$ are the hydraulic residence time at which algae were cultured and the minimum value for $H R T$, respectively, and $i, j$, and $k$ are fitted constants.

For the $100 \mathrm{mg} / \mathrm{L}$ treatment, the $\mathrm{r}^{2}$ is 0.93 . From this equation, the maximum Chl/cell was produced at an HRT of 14 days. The equation does not fit the data for the $1000 \mathrm{mg} / \mathrm{L}$ treatment as well as the $100 \mathrm{mg} / \mathrm{L}$, with an $\mathrm{r}^{2}$ of 0.40 from Equation (10). At a small HRT (2-10), the $1000 \mathrm{mg} / \mathrm{L}$ treatment increased the $Y$ by an average of $6 \times$ over the control. The $Y$ then decreased from between $H R T$ values of 12 and 25 days $\left(100 \mathrm{mg} / \mathrm{L} \mathrm{TiO}_{2}\right)$ to between $H R T$ values of 3 and $1(1000 \mathrm{mg} / \mathrm{L} \mathrm{TiO})_{2}$.

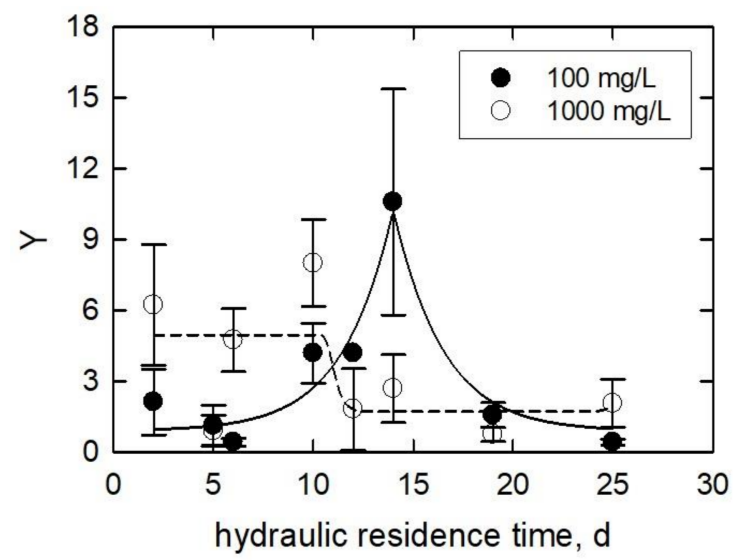

Figure 7. Normalized specific chlorophyll a plotted against the hydraulic residence time of the continually stirred tank reactors in which the algae inoculums were cultured. Lines are fitted using Equation (11).

Kulandaivelu and Senger [60] showed an 85-98\% decrease in photosynthetic activity from Scenedesmus obliquus, heterotrophically grown algae for 10-30 days, respectively. In another study, a decline in photosynthesis rate was reported when algal culture gradually reached the stationary growth phase [61]. Cheregi et al. [62] studied the presence of state transitions in different culturing ages of Guillardia theta in terms of Chl $a$ and $c$ measurement. The algae were grown for 1-2 days (early logarithmic phase), 2-6 days (logarithmic phase), 6-9 days (early stationary phase), and 9-13 days (late stationary phase). Their result showed that the amount of Chl $a$ and $c$ declined from $1.34 \mathrm{pg} / \mathrm{cell}$ (2-day culture) to $0.750 \mathrm{pg} /$ cell (13-day culture). Oukarroum [63] evaluated the photosynthetic activity of $C$. vulgaris and S. obliquus from different growth phases using in vivo Chl a fluorescence transient measurement. Algae age and species significantly affected the photosynthetic activity that, after 20 days, Chl a content declined by $84 \%$ in C. vulgaris and $89 \%$ in S. obliquus compared to the values from Day 3. Figure 8 is the normalized specific lipid peroxidation $(Z)$ plotted as a function of HRT. In most cases, $Z$ results were greater for the $1000 \mathrm{mg} / \mathrm{L}$ treatment than the $100 \mathrm{mg} / \mathrm{L}$ treatment. There is no clear trend in the data. The maximum $Z$ of $4.0 \pm 2.5$ occurred in the $100 \mathrm{mg} / \mathrm{L}$ treatment at an HRT of 10 days, while the minimum of $1.1 \pm 0.6$ occurred in this treatment at an HRT of 2 days. The maximum and minimum $Z$ values for the $1000 \mathrm{mg} / \mathrm{L}$ treatment were $5.8 \pm 4.5$ and $0.68 \pm 0.16$ at $H R T$ values of 10 and 6 days, respectively. In all but in three cases, the $1000 \mathrm{mg} / \mathrm{L}$ treatment generated more lipid peroxidation. Two of those cases had similar values with relatively small standard deviations. 
Comparison between the two treatments shows that the $Z$ trends are the same, i.e., the slopes increase or decrease together. When the $Z$ was plotted against the growth rate (calculated by Equation (12), day $^{-1}$ ) of the control samples, a trend emerged (Figure 9).

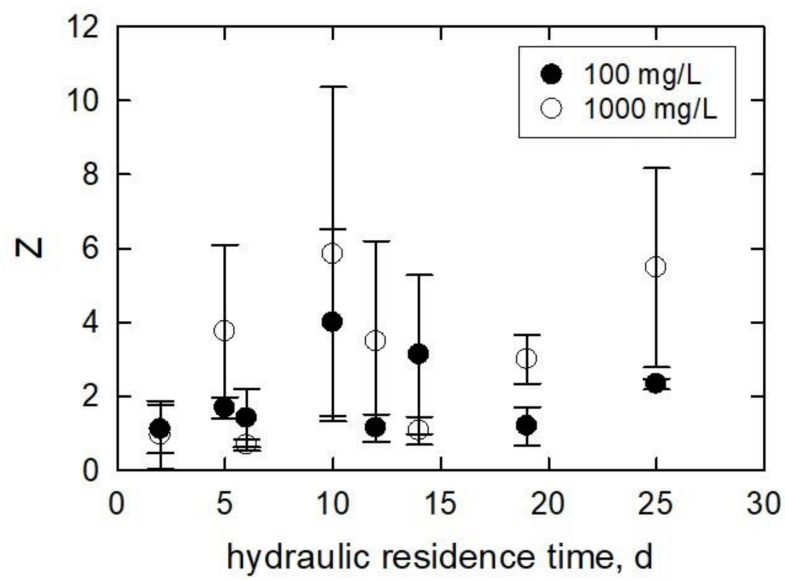

Figure 8. Normalized specific lipid peroxidation $(Z)$ plotted against the hydraulic residence time of the continually stirred tank reactors in which the algae inoculums were cultured.

$$
k=\frac{\ln \left(\rho_{i}\right)-\ln \left(\rho_{f}\right)}{\Delta t}
$$

$k$ is the growth rate of the controls under experimental conditions $\left(\mathrm{d}^{-1}\right)$ of each $H R T, \rho_{i}$ is the initial cell density of the controls of each $H R T$ (cells $/ \mathrm{mL}$ ), $\rho_{\mathrm{t}}$ is the final cell density of the controls of each $H R T$ at the end of the experimental duration (cell $/ \mathrm{mL}$ ), and $\Delta \mathrm{t}$ is the duration of the experiment $(\mathrm{d})$. At low growth rates (0.35-0.6), the lipid peroxidation per cell was about $6 \times$ and $3 \times$ greater than the control for the 1000 and $100 \mathrm{mg} / \mathrm{L}$ treatments, respectively. Only in one case $\left(0.41\right.$ day $\left.^{-1}\right)$ was the $Y$ lower in the $1000 \mathrm{mg} / \mathrm{L}$ treatment than in the $100 \mathrm{mg} / \mathrm{L}$ treatment. At growth rates $>0.6$, the $Y$ had values similar to those of the control samples in the $100 \mathrm{mg} / \mathrm{L}$ treatment. The $1000 \mathrm{mg} / \mathrm{L}$ treatment caused the $Y$ to decrease to control values as well; however, one sample produced higher $Y$ at $4 \times$ the control at 0.72 day $^{-1}$.

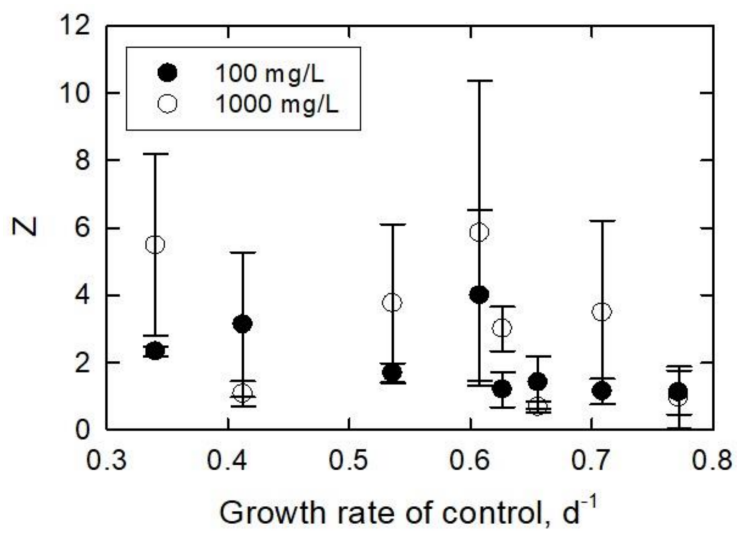

Figure 9. Normalized specific lipid peroxidation plotted against the measured growth rates of the control samples.

It is a well-known phenomenon that $\mathrm{TiO}_{2} \mathrm{NPs}$ can generate reactive oxygen species (ROS) and hydroxyl radicals $(\mathrm{OH} \cdot)$ under UV light. As being strong oxidants, ROS can decompose organic materials (i.e., cell surfaces) $[64,65]$. ROS cause oxidative stress, which leads to lipid peroxidation 
and toxicity to organisms [26,46,66-69]. In our previous studies [20,21], we have shown the growth inhibition of green algae, $R$. subcapitata, exposed to $\mathrm{TiO}_{2} \mathrm{NPs}$ under fluorescence light irradiation. Lee and An [18] have shown the inhibition of R. subcapitata growth under visible light, UVA, and UVB irradiation conditions.

Kadukova et al. [70] employed algae Parachlorella kessleri from different culturing weeks (1-4 weeks) to produce Ag NPs. UV-visible spectral analysis was performed, and maximum peaks were obtained from one-week cultures. Within 14 days, culture age (1-4 weeks) and the Ag NP formation showed a linear relationship. After 15 days, the Ag NP production rate decreased in 1, 3 and 4 week cultures. Adeleye et al. [71] evaluated the effect of sulfide/silica-modified nZVI (FeSSi) on Chlamydomonas reinhardtii algae cultured for 1, 2, or 11 days. Regardless of the exposed FeSSi doses (1.8 and $18 \mathrm{mg} / \mathrm{L})$, one-day cultures were more sensitive than 11-day cultures.

\section{Conclusions}

This research was undertaken to determine how population density affects the toxicity of $35.1 \pm 2.1 \mathrm{~nm} \mathrm{TiO} 2$ and how algae physiology affects the toxicity of $\mathrm{TiO}_{2}$.

First, varying the initial algae cell concentration resulted in two reactions to the same mass of NPs. At high body burdens, there was an increase in $Z$ and $Y$, while $R_{s}$ was depressed. $Z$ results indicate that direct contact between NPs and algae increased lipid peroxidation due to the loading. ROS reaction rates are relatively fast in aqueous systems. Therefore, direct transfer of the ROS to surface lipids or carbohydrates will disrupt the cell wall/membrane functions.

Hydraulic retention varies the age of algae. The age of algae affects many physiological parameters. This includes the lipid content and growth rates of the algae. The toxicity of nano- $\mathrm{TiO}_{2}$ is age-dependent in the studied system. The toxicity/stress of NPs may be diluted on a per cell basis in fast growing samples. Thus, the physio-kinetics of growth and nanoparticle interaction is important. Additionally, age affects the composition of the cultures as well. ROS were more likely to affect the higher lipid content cells. This can be important in the environment, as time of year is affects the algae response to NPs.

The exposure regime must be taken into consideration when interpreting the toxicity of photocatalytic NPs with a $35.1 \pm 2.1 \mathrm{~nm} \mathrm{TiO}_{2}$ diameter. Additional NP sizes should be investigated for similar findings.

Acknowledgments: This study was funded by USEPA STAR Grant no. R-83172101. The nanoparticles were purchased from Degussa Corp. The authors have no direct financial interest in or relationship with USEPA and Degussa Corp.

Author Contributions: Chin Pao Huang conceived and supervised the project; David M. Metzler performed the experiments; David M. Metzler and Ayca Erdem analyzed the data and wrote the paper.

Conflicts of Interest: The authors declare no conflicts of interest.

\section{References}

1. Galley, E.; Fardell, N.A. Sunscreen with Coated Microfine Particles. U.S. Patent 5,609,852, 11 March 1997.

2. Canesi, L.; Fabbri, R.; Gallo, G.; Vallotto, D.; Marcomini, A.; Pojana, G. Biomarkers in Mytilus galloprovincialis exposed to suspensions of selected nanoparticles (Nano carbon black, C60 fullerene, Nano-TiO ${ }_{2}, \mathrm{Nano}_{-} \mathrm{SiO}_{2}$ ). Aquat. Toxicol. 2010, 100, 168-177. [CrossRef] [PubMed]

3. Clemente, Z.; Castro, V.L.; Jonsson, C.M.; Fraceto, L.F. Minimal levels of ultraviolet light enhance the toxicity of $\mathrm{TiO}_{2}$ nanoparticles to two representative organisms of aquatic systems. J. Nanopart. Res. 2014, 16, 2559. [CrossRef]

4. Weir, A.; Westerhoff, P.; Fabricius, L.; Hristovski, K.; von Goetz, N. Titanium dioxide nanoparticles in food and personal care products. Environ. Sci. Technol. 2012, 46, 2242-2250. [CrossRef] [PubMed]

5. Robichaud, C.O.; Uyar, A.E.; Darby, M.R.; Zucker, L.G.; Wiesner, M.R. Estimates of upper bounds and trends in nano- $\mathrm{TiO}_{2}$ production as a basis for exposure assessment. Environ. Sci. Technol. 2009, 43, 4227-4233. [CrossRef] [PubMed] 
6. Piccinno, F.; Gottschalk, F.; Seeger, S.; Nowack, B. Industrial production quantities and uses of ten engineered nanomaterials in Europe and the world. J. Nanopart. Res. 2012, 14, 1109. [CrossRef]

7. Keller, A.A.; McFerran, S.; Lazareva, A.; Suh, S. Global life cycle releases of engineered nanomaterials. J. Nanopart. Res. 2013, 15, 1692-1709. [CrossRef]

8. Boxall, A.; Chaudhry, Q.; Sinclair, C.; Jones, A.; Aitken, R.; Jefferson, B.; Watts, C. Current and Future Predicted Environmental Exposure to Engineered Nanoparticles; Central Science Laboratory: York, UK, 2007.

9. Mueller, N.; Nowack, B. Exposure modeling of engineered nanoparticles in the environment. Environ. Sci. Technol. 2008, 42, 4447-4453. [CrossRef] [PubMed]

10. Gottschalk, F.; Ort, C.; Scholz, R.W.; Nowack, B. Engineered nanomaterials inrivers-exposure scenarios for Switzerland at high spatial and temporal resolution. Environ. Pollut. 2011, 159, 3439-3445. [CrossRef] [PubMed]

11. Gottschalk, F.; Lassen, C.; Kjoelholt, J.; Christensen, F.; Nowack, B. Modeling flows and concentrations of nine engineered nanomaterials in the Danish environment. Int. J. Environ. Res. Public Health 2015, 12, 5581-5602. [CrossRef] [PubMed]

12. Stumm, W.; Morgan, J.J. Aquatic Chemistry: Chemical Equilibria and Rates in Natural Waters, 3rd ed.; John Wiley \& Sons, Inc.: New York, NY, USA, 1996.

13. Oomen, A.G.; Bleeker, E.A.J.; Bos, P.M.J.; van Broekhuizen, F.; Gottardo, S.; Groenewold, M.; Hristozov, D.; Hund-Rinke, K.; Irfan, M.A.; Marcomini, A.; et al. Grouping and Read-Across Approaches for Risk Assessment of Nanomaterials. Int. J. Environ. Res. Public Health 2015, 12, 13415-13434. [CrossRef] [PubMed]

14. Bos, P.M.J.; Gottardo, S.; Scott-Fordsmand, J.J.; van Tongeren, M.; Semenzin, E.; Fernandes, T.F.; Hristozov, D.; Hund-Rinke, K.; Hunt, N.; Irfan, M.A.; et al. The MARINA Risk Assessment Strategy: A Flexible Strategy for Efficient Information Collection and Risk Assessment of Nanomaterials. Int. J. Environ. Res. Public Health 2015, 12, 15007-15021. [CrossRef] [PubMed]

15. Teske, S.S.; Detweiler, C.S. The Biomechanisms of Metal and Metal-Oxide Nanoparticles' Interactions with Cells. Int. J. Environ. Res. Public Health 2015, 12, 1112-1134. [CrossRef] [PubMed]

16. Adams, L.K.; Lyon, D.Y.; Alvarez, P.J.J. Comparative eco-toxicity of nanoscale $\mathrm{TiO}_{2}, \mathrm{SiO}_{2}$, and $\mathrm{ZnO}$ water suspensions. Water Res. 2006, 40, 3527-3532. [CrossRef] [PubMed]

17. Amiano, I.; Olabarrieta, J.; Vitorica, J.; Zorita, S. Acute toxicity of nanosized $\mathrm{TiO}_{2}$ to Daphnia magna under UVA irradiation. Environ. Toxicol. Chem. 2012, 31, 2564-2566. [CrossRef] [PubMed]

18. Lee, W.; An, Y.J. Effects of zinc oxide and titanium dioxide nanoparticles on green algae under visible, UVA, and UVB irradiations: No evidence of enhanced algal toxicity under UV pre-irradiation. Chemosphere 2013, 91, 536-544. [CrossRef] [PubMed]

19. Sendra, M.; Moreno-Garrido, I.; Yeste, M.P.; Gatica, J.M.; Blasco, J. Toxicity of $\mathrm{TiO}_{2}$, in nanoparticle or bulk form to freshwater and marine microalgae under visible light and UV-A radiation. Environ. Pollut. 2017, 227, 39-48. [CrossRef] [PubMed]

20. Metzler, D.; Li, M.; Erdem, A.; Huang, C.P. Responses of algae to photocatalytic nano-TiO 2 particles with an emphasis on the effect of particle size. Chem. Eng. J. 2011, 170, 538-546. [CrossRef]

21. Metzler, D.; Erdem, A.; Tseng, Y.H.; Huang, C.P. Responses of algal cells to engineered nanoparticles measured as algal cell population, chlorophyll a, and lipid peroxidation: Effect of particle size and type. J. Nanotechnol. 2012, 2012, 237284. [CrossRef]

22. Ma, H.; Brennan, A.; Diamond, S.A. Phototoxicity of $\mathrm{TiO}_{2}$ nanoparticles under solar radiation to two aquatic species: Daphnia magna and Japanese medaka. Environ. Toxicol. Chem. 2012, 31, 1621-1629. [CrossRef] [PubMed]

23. Li, S.; Wallis, L.K.; Diamond, S.A.; Ma, H.; Hoff, D.J. Species sensitivity and dependence on exposure conditions impacting the phototoxicity of $\mathrm{TiO}_{2}$ nanoparticles to benthic organisms. Environ. Toxicol. Chem. 2014, 33, 1563-1569. [CrossRef] [PubMed]

24. Li, S.; Wallis, L.K.; Ma, H.; Diamond, S.A. Phototoxicity of $\mathrm{TiO}_{2}$ nanoparticles to a freshwater benthic amphipod: Are benthic systems at risk? Sci. Total Environ. 2014, 466-467, 800-808. [CrossRef] [PubMed]

25. Faria, M.; Navas, J.M.; Soares, A.M.; Barata, C. Oxidative stress effects of titanium dioxide nanoparticle aggregates in zebrafish embryos. Sci. Total Environ. 2014, 470-471, 379-389. [CrossRef] [PubMed]

26. Ozkaleli, M.; Erdem, A. Biotoxicity of $\mathrm{TiO}_{2}$ nanoparticles on Raphidocelis subcapitata microalgae exemplified by membrane deformation. Int. J. Environ. Res. Public Health 2018, 15, 416. [CrossRef] [PubMed] 
27. Mansfield, C.M.; Alloy, M.M.; Hamilton, J.; Verbeck, G.F.; Newton, K.; Klaine, S.J.; Roberts, A.P. Photo-induced toxicity of titanium dioxide nanoparticles to Daphnia magna under natural sunlight. Chemosphere 2015, 120, 206-210. [CrossRef] [PubMed]

28. Farkas, J.; Peter, H.; Ciesielski, T.M.; Thomas, K.V.; Sommaruga, R.; Salvenmoser, W.; Weyhenmeyer, G.A.; Tranvik, L.J.; Jenssen, B.M. Impact of $\mathrm{TiO}_{2}$ nanoparticles on freshwater bacteria from three Swedish lakes. Sci. Total Environ. 2015, 535, 85-93. [CrossRef] [PubMed]

29. Oukarroum, A.; Zaidi, W.; Samadani, M.; Dewez, D. Toxicity of nickel oxide nanoparticles on a freshwater green algal strain of Chlorella vulgaris. Biomed. Res. Int. 2017, 2017, 9528180. [CrossRef] [PubMed]

30. OECD. Freshwater Alga and Cyanobacteria, Growth Inhibition Test; Organization for Economic Co-operation and Development: Paris, France, 2006.

31. USEPA. Short-Term Methods for Estimating the Chronic Toxicity of Effluents and Receiving Waters to Freshwater Organisms, 4th ed.; EPA-821-R-02-013; U.S. Environmental Protection Agency, Office of Water: Washington, DC, USA, 2002.

32. ISO. Water Quality-Fresh Water Algal Growth Inhibition Test with Unicellular Green Algae; International Organization for Standardization: Geneva, Switzerland, 2002.

33. Creswell, L. Phytoplankton culture for aquaculture feed. SRAC 2010, 5004, 1-16. Available online: http: / / www2.ca.uky.edu/wkrec/PhytoplanktonAlgaeCulture.pdf (accessed on 8 January 2018).

34. Hoang, T.C.; Klaine, S.J. Influence of organism age on metal toxicity to Daphnia magna. Environ. Toxicol. Chem. 2007, 26, 1198-1204. [CrossRef] [PubMed]

35. Rogevich, E.C.; Hoang, T.C.; Rand, G.M. The effects of water quality and age on the acute toxicity of copper to the florida apple snail, Pomacea paludosa. Arch. Environ. Contam. Toxicol. 2008, 54, 690-696. [CrossRef] [PubMed]

36. Lesser, M.P. Elevated temperatures and ultraviolet radiation cause oxidative stress and inhibit photosynthesis in symbiotic dinoflagellates. Limnol. Oceanogr. 1996, 41, 271-283. [CrossRef]

37. Hoang, T.C.; Tomasso, J.R.; Klaine, S.J. Influence of water quality and age on nickel toxicity to fathead minnows (Pimephales promelas). Environ. Toxicol. Chem. 2004, 23, 86-92. [CrossRef] [PubMed]

38. Stevenson, L.M.; Dickson, H.; Klanjscek, T.; Keller, A.A.; McCauley, E.; Nisbet, R.M. Environmental feedbacks and engineered nanoparticles: Mitigation of silver nanoparticle toxicity to Chlamydomonas reinhardtii by algal-produced organic compounds. PLoS ONE 2013, 8, e74456. [CrossRef] [PubMed]

39. Moreno-Garrido, I.; Lubián, L.M.; Soares, A.M.V.M. Influence of cellular density on determination of EC50 in microalgal growth inhibition tests. Ecotoxicol. Environ. Saf. 2000, 47, 112-116. [CrossRef] [PubMed]

40. Warheit, D.B.; Hoke, R.A.; Finlay, C.; Donner, E.M.; Reed, K.L.; Sayes, C.M. Development of a base set of toxicity tests using ultrafine $\mathrm{TiO}_{2}$ particles as a component of nanoparticle risk. Toxicol. Lett. 2007, 17, 99-110. [CrossRef] [PubMed]

41. Hartmann, N.B.; Von der Kammer, F.; Hofmann, T.; Baalousha, M.; Ottofuelling, S.; Baun, A. Algal testing of titanium dioxide nanoparticles-Testing considerations, inhibitory effects and modification of cadmium bioavailability. Toxicology 2010, 269, 190-197. [CrossRef] [PubMed]

42. Aruoja, V.; Dubourguier, H.C.; Kasemets, K.; Kahru, A. Toxicity of nanoparticles of $\mathrm{CuO}, \mathrm{ZnO}$ and $\mathrm{TiO}_{2}$ to microalgae Pseudokirchneriella subcapitata. Sci. Total Environ. 2009, 407, 1461-1468. [CrossRef] [PubMed]

43. Metzler, D. Effect of Food-Borne Cadmium on the Reproduction of Ceriodaphnia Dubia. Master's Thesis, University of Delaware, Newark, DE, USA, 2003.

44. National Renewable Energy Laboratory (NREL). Best Practices Handbook for the Collection and Use of Solar Resource Data for Solar Energy Applications, 2nd ed.; Sengupta, M., Habte, A., Gueymard, C., Wilbert, S., Renné, D., Stoffel, T.U.S., Eds.; Department of Energy Office of Energy Efficiency \& Renewable Energy Operated by the Alliance for Sustainable Energy: Alexandria, VA, USA, 2017; p. 233.

45. Weber, C.I.; Fay, L.A.; Collins, G.B.; Rathke, D.E.; Tobin, J. Review of Methods for the Analysis of Chlorophyll in Periphyton and Plankton of Marine and Freshwater Systems; Ohio State University Sea Grant Program Technical Bulletin, OHSU-TB-15, 1-71; Ohio State University: Columbus, OH, USA, 1986.

46. Maness, P.C.; Smolinski, S.; Blake, D.M.; Huang, Z.; Wolfrum, E.J.; Jacoby, W.A. Bactericidal activity of photocatalytic $\mathrm{TiO}_{2}$ reaction: Toward an understanding of its killing mechanism. Appl. Environ. Microbiol. 1999, 65, 4094-4098. [PubMed] 
47. Ottofuelling, S.; Von der Kammer, F.; Hofmann, T. Commercial titanium dioxide nanoparticles in both natural and synthetic water: Comprehensive multidimensional testing and prediction of aggregation behavior. Environ. Sci. Technol. 2011, 45, 10045-10052. [CrossRef] [PubMed]

48. Raza, G.; Amjad, M.; Kaur, I.; Wen, D. Stability and aggregation kinetics of titania nanomaterials under environmentally realistic conditions. Environ. Sci. Technol. 2016, 50, 8462-8472. [CrossRef] [PubMed]

49. Lin, M.; Tseng, Y.H.; Huang, C.P. Interactions between nano- $\mathrm{TiO}_{2}$ particles and algal cells at moderate particle concentration. Front. Chem. Sci. Eng. 2015, 9, 242-257. [CrossRef]

50. Hoffmann, M.R.; Martin, S.T.; Choi, W.; Bahnemann, D.W. Environmental Applications of Semiconductor Photocatalysis. Chem. Rev. 1995, 95, 69-96. [CrossRef]

51. Kosmulski, M. pH-dependent surface charging and points of zero charge. IV. Update and new approach. J. Colloid Interface Sci. 2009, 337, 439-448. [CrossRef] [PubMed]

52. Guzman, K.A.; Finnegan, M.P.; Banfield, J.F. Influence of surface potential on aggregation and transport of titania nanoparticles. Environ. Sci. Technol. 2006, 40, 7688-7693. [CrossRef] [PubMed]

53. Othman, S.H.; Rashid, S.A.; Ghazi, T.I.M.; Abdullah, N. Dispersion and stabilization of photocatalytic $\mathrm{TiO}_{2}$ nanoparticles in aqueous suspension for coatings applications. J. Nanomater. 2012, 2012, 2. [CrossRef]

54. Wu, H.; Jiang, H.; Liu, C.; Deng, Y. Growth, pigment composition, chlorophyll fluorescence and antioxidant defenses in red alga Gracilaria. S. Afr. J. Bot. 2012, 100, 27-32. [CrossRef]

55. Dietz, K.J.; Turkan, I.; Krieger-Liskay, A. Redox-and reactive oxygen species-dependent signaling into and out of the photosynthesizing chloroplast. Plant Physiol. 2016, 171, 1541-1550. [CrossRef] [PubMed]

56. Muyssen, B.T.A.; Janssen, C.R. Age and exposure duration as a factor influencing $\mathrm{Cu}$ and $\mathrm{Zn}$ toxicity toward Daphnia magna. Ecotoxicol. Environ. Saf. 2007, 68, 436-442. [CrossRef] [PubMed]

57. Yu, R.Q.; Wang, W.X. Kinetic uptake of bioavailable cadmium, selenium, and zinc by Daphnia magna. Environ. Toxicol. Chem. 2002, 21, 2348-2355. [CrossRef] [PubMed]

58. Hutchinson, T.H.; Solbe', J.; Kloepper-Sams, P.J. Analysis of the ecetoc aquatic toxicity (EAT) database III -Comparative toxicity of chemical substances to different life stages of aquatic organisms. Chemosphere 1998, 36, 129-142. [CrossRef]

59. Stuhlbacher, A.; Bradley, M.C.; Naylor, C.; Calow, P. Variation in the development of cadmium resistance in Daphnia magna straus; Effect of temperature, nutrition, age and genotype. Environ. Pollut. 1993, 80, 153-158. [CrossRef]

60. Kulandaivelu, G.; Senger, H. Changes in the reactivity of the photosynthetic apparatus in heterotrophic ageing cultures of Scenedesmus obliquus. I. Changes in the Photochemical Activities. Physiol. Plant. 1976, 36, 157-164. [CrossRef]

61. Samuelsson, G.; Öquist, G. A method for studying photosynthetic capacities of unicellular algae based on in vivo chlorophyll fluorescence. Physiol. Plant. 1977, 40, 315-319. [CrossRef]

62. Cheregi, O.; Kotabová, E.; Prášil, O.; Schröder, W.P.; Kaňa, R.; Funk, C. Presence of state transitions in the cryptophyte alga Guillardia theta. J. Exp. Bot. 2015, 66, 6461-6470. [CrossRef] [PubMed]

63. Oukarroum, A. Change in photosystem II photochemistry during algal growth phases of Chlorella vulgaris and Scenedesmus obliquus. Curr. Microbiol. 2016, 72, 692-699. [CrossRef] [PubMed]

64. Christensen, P.; Curtis, T.P.; Egerton, T.A.; Kosa, S.A.M.; Tinlin, J.R. Photoelectrocatalytic and photocatalytic disinfection of E. coli suspensions by titanium dioxide. Appl. Catal. B Environ. 2003, 41, 376-386. [CrossRef]

65. Schneider, J.; Matsuoka, M.; Takeuchi, M.; Zhang, J.; Horiuchi, Y.; Anpo, M.; Bahnemann, D.W. Understanding $\mathrm{TiO}_{2}$ photocatalysis: Mechanisms and materials. Chem. Rev. 2014, 114, 9919-9986. [CrossRef] [PubMed]

66. Nel, A.; Xia, T.; Mädler, L.; Li, N. Toxic potential of materials at the nanolevel. Science 2006, 311, 622-627. [CrossRef] [PubMed]

67. Kelly, S.A.; Havrilla, C.M.; Brady, T.C.; Abramo, K.H.; Levin, E.D. Oxidative stress in toxicology: Established mammalian and emerging piscine model systems. Environ. Health Perspect. 1998, 106, 375-384. [CrossRef] [PubMed]

68. Kim, K.; Klaine, S.J.; Cho, J.; Kim, S.H.; Kim, S.D. Oxidative stress responses of Daphnia magna exposed to $\mathrm{TiO}_{2}$ nanoparticles according to size fraction. Sci. Total Environ. 2010, 408, 2268-2272. [CrossRef] [PubMed]

69. Long, T.C.; Saleh, N.; Tilton, R.D.; Lowry, G.V.; Veronesi, B. Titanium Dioxide (P25) produces reactive oxygen species in immortalized brain microglia (BV2): Implications for nanoparticle neurotoxicity. Environ. Sci. Technol. 2006, 40, 4346-4352. [CrossRef] [PubMed] 
70. Kaduková, J.; Velgosová, O.; Mražíková, A.; Marcinčáková, R. The effect of culture age and initial Silver concentration on biosynthesis of Ag nanoparticles. Nova Biotechnol. Chim. 2014, 13, 28-37. [CrossRef]

71. Adeleye, A.S.; Stevenson, L.M.; Su, Y.; Nisbet, R.M.; Zhang, Y.; Keller, A.A. Influence of phytoplankton on fate and effects of modified zerovalent iron nanoparticles. Environ. Sci. Technol. 2016, 50, 5597-5605. [CrossRef] [PubMed]

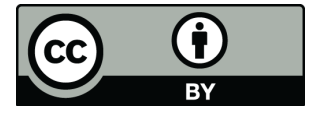

(C) 2018 by the authors. Licensee MDPI, Basel, Switzerland. This article is an open access article distributed under the terms and conditions of the Creative Commons Attribution (CC BY) license (http:/ / creativecommons.org/licenses/by/4.0/). 